\title{
Juxtaoral organ: an anatomical finding to be considered
}

\author{
V. Ramos-Vega, I. Roa \\ Morphology Unit, Department of Biomedical Basic Sciences, Faculty of Health Sciences, University of Talca, Chile
}

[Received: 26 November 2018; Accepted: 10 January 2019]

The juxtaoral organ (JOO) is a vestigial anatomical structure which is not usually described in lectures and classic texts of general histology and oral histology, despite it being included in the "Terminologia Histologica: International terms for human cytology and histology". Although there is evidence about its histological structure, there are no macroscopic anatomical reports about it. We report the finding of a structure of glandular macroscopic appearance in a horizontal section of a plastinated human head belonging to the Morphology Laboratory of the Department of Biomedical Basic Sciences at the University of Talca. Due to its location, dimensions and anatomical relations, we determined it to be the JOO. Using a digital calliper, we measured the anteroposterior and transverse dimensions of the JOO and observed its anatomical relationships with neighbouring structures of clinical relevance. We conclude that the $\mathrm{JOO}$ is relevant to surgical practice due to its anatomical relations with relevant structures such as inferior third molar and lingual nerve. Its clinical application lies in the differential diagnosis with invasive processes of malignant neoplasia originating in the oral cavity. (Folia Morphol 2019; 78, 3: 643-646)

Key words: diagnostic errors, differential diagnosis, mouth neoplasms, juxtaoral organ

\section{INTRODUCTION}

The juxtaoral organ (JOO) is a vestigial anatomical structure first described in 1885 by Danish anatomist Johan Chievitz from studies on the development of salivary glands in human embryos [4]. Although at first it was considered a temporary structure of glandular development in the embryonic stage, its persistence was later reported in adults [27]. Its existence and characteristics are not usually described in lectures and classic texts of general histology and oral histology despite it being included in the "Terminologia Histologica: International terms for human cytology and histology" (FICAT, 2008), as the Organum yuxtaorale (H3.04.01.0.00019).

The $\mathrm{JOO}$ is located in the infratemporal region at the level of the submucosa associated with the retromolar trigone, medial to the medial pterygoid muscle, where it is related to the pterygomandibular raphe [23]. It is a small, tapered structure that is not obvious macroscopically, but that is usually a finding made during oral surgery procedures and analysis of biopsies for histopathological studies.

Embryologically, the JOO arises from the epithelium of the lower segment the transverse opening of the stomodeum during O'Rahilly stage 16 , subsequently separating from the epithelium in O'Rahilly stage 18 [14], although other authors suggest the JOO represents an elongation of the parotid gland [28] mainly due to the genetic similarity of the two structures [8].

Histologically it is composed of an epithelial parenchyma included in a stroma of richly innervated organised connective tissue [28]. The parenchyma is made up 




Figure 1. A. Horizontal section of a plastinated head at C2 level, lower view; B. Horizontal section of a plastinated head at C2 level, upper view (section consecutive to "A"). In both, the blue arrowheads indicate the juxtaoral organ.

of multilobed epithelial cells consisting of circumscribed nests of squamous, columnar and occasionally basaloid non-keratinising epithelial cells with a defined glandular or organoid pattern with no keratin formation [4].

The function of the JOO is indeterminate, although immunohistochemical studies $[3,9,19,23]$ show that it is neuroepithelial and glandular in nature, being for some authors a structure with mechanoreceptor characteristics $[5,13]$. In any case, it does not seem to play a relevant role in the functions of the stomatognathic apparatus, which reinforces the idea of its vestigial nature. Nevertheless, knowing its location and histological characteristics is valuable because several authors have reported that its presence in surgical specimens subjected to histopathological analysis with a diagnosis of squamous cell carcinoma may be confused with a perineural invasion of tumour cells $[10,24]$, which can have considerable influence on a patient's prognosis.

Plastination technique is a preservation method of biological material in the long term, which consists in the replacement of water and lipids of a tissue sample, body parts or complete bodies, by reactive polymers $[7,18]$. In general terms, the technique consist of subjecting the desired sample to a process of fixation, dehydration/degreasing, forced impregnation of the polymer under vacuum and final curing in the oven [7]. As a result dry, odourless samples which not deteriorate in time and allow studying anatomical structures and their natural relations are obtained, being useful as a tool for the teaching of anatomy and research.

In this light, we present a case report of the finding of a structure, the characteristics of which correspond to the $\mathrm{JOO}$ in samples from adult cadaver material preserved by plastination.

\section{CASE REPORT}

The finding was made during the analysis of a set of horizontal head sections from an adult Asian male cadaver, preserved by plastination, belonging to the Morphology Laboratory of the Department of Biomedical Basic Sciences at the Universidad de Talca, Chile.

A bilateral structure of glandular appearance was observed, tapered and extended from front to back, located in the submucosa of the retromolar trigone at the level of the pterygomandibular raphe, medial to the mandibular ramus, anteromedial to the medial pterygoid muscle and lateral to the base of the tongue (Fig. 1). The structure is closely related posteriorly with the lingual nerve and related medial with the roots of the lower third molar, from which it is separated by a thin layer of cortical bone and around $1 \mathrm{~mm}$ of cancellous bone (Fig. 2).

A digital calliper (VWR, Radnor, PA, USA) was used to note the dimensions of the finding, observing that the right side presented an anteroposterior diameter of $9.88 \mathrm{~mm}$ and a transverse diameter of $6.4 \mathrm{~mm}$, whereas the left side had an anteroposterior diameter of $11.4 \mathrm{~mm}$ and a transverse diameter of $5.6 \mathrm{~mm}$ (Fig. 2).

Considering its morphology, location, anatomical relations, and ruling out that the structure corresponds to other glandular elements belonging to the normal anatomy identifiable in other sections, we determined it to be the JOO.

\section{DISCUSSION}

Although there are several reports in the literature around the histological and functional characteristics of the JOO, few describe its presence in cadaver specimens, there being no description in sections of a plastinated cadaver, a technique that enables us 


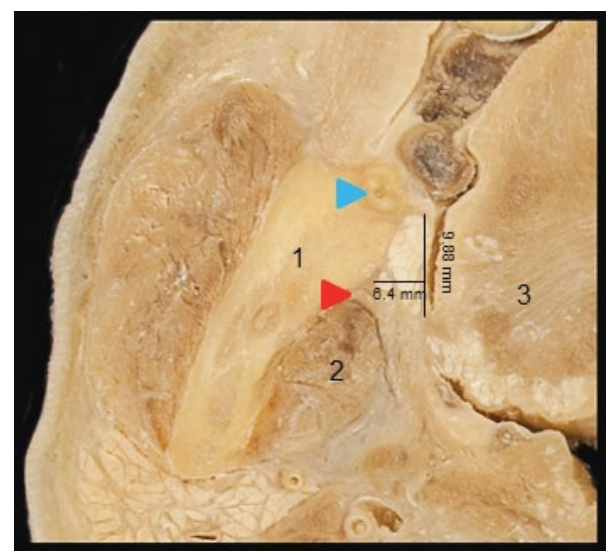

Figure 2. Magnification of the section observed in Figure 1A (right side). The juxtaoral organ ( $\mathrm{JOO}$ ) is observed at the site of the retromolar trigone, medial to the mandibular ramus (1), anteromedial to the medial pterygoid muscle (2) and lateral to the base of the tongue (3). Note the close relation to the roots of lower third molar (blue arrowhead) and lingual nerve (red arrowhead). The lines represent the way in which the dimensions of the $\mathrm{JOO}$ were measured anteroposteriorly and transversally.

to recognise clearly and with a faithful approach to reality the location and topographical relations of different anatomical structures.

In our case the JOO appeared bilaterally, which agrees with what was described by lto et al. [10] and Sancheti et al. [24], while the location and relations observed are consistent with what has been established in the literature $[2,16,25]$, ruling out the possibility that it is an accessory parotid gland, as this presents a more superficial location and is relative to the parotid duct [21]. In our finding we observed a close proximity of the JOO to the roots of lower third molar, which could imply its exposure and/or damage during oral surgeries, although due to the little or no functionality that it seems to have, we consider that this damage might not be relevant to an individual's physiology.

The observed dimensions are generally consistent with those reported in the literature, which describes the JOO as presenting highly variable dimensions, with an anteroposterior diameter that varies between 7 and $17 \mathrm{~mm}$ and a transverse diameter that varies between 1 and $7 \mathrm{~mm}[15,26]$. In our case the JOO had an average anteroposterior diameter of $10.6 \mathrm{~mm}$ and an average transverse diameter of $6 \mathrm{~mm}$.

Histologically the JOO is made up of nests or cords of epithelial cells that resemble a non-keratinised flat stratified epithelium with peripheral basal cells in a palisade arrangement, as well as some cylindrical cells with clear cytoplasm forming cords or glandu- lar-like tubular structures that can at times present an associated secretion product negative for mucin [24]. The epithelial cells of the JOO do not present mitotic figures and they may occasionally be associated with dystrophic calcifications. Furthermore, it presents a stroma of surrounding connective tissue associated with the presence of myelinated and unmyelinated nerve fibres from the buccal nerve $[17,26]$.

Several studies show the embryonic development of JOO in multiple species of mammals and reptiles, which suggests that this structure could be relevant in an embryological process related to evolutionary development [22]. Some authors suggest that could be a phylogenetic vestige of the salivary gland development $[8,22]$, however several studies on the embryonic development of JOO carried out in both humans and other species, have shown that the origin of both structures is different $[8,10,14]$. Despite the fact that JOO has been studied more frequently in humans, there are morphological studies that describe in detail the organogenesis and anatomy of this structure in mice [10], which have a longer JOO than humans with different anatomical relationships, suggesting differences according to the phylogenetic order and the functional demands of different species, although studies of comparative anatomy and embryogenesis in other species are needed to support this idea.

From the clinical point of view, the JOO is relevant for the histopathological study of an oral mucosa lesion. Histopathological studies have reported biopsy samples with a diagnosis of oral cancer, showing epithelial structures associated with nerve fibres adjacent to the primary tumour which resemble the process of perineural invasion of a malignant neoplasia, thus leaving open the possibility of a misdiagnosis if the existence of JOO is not considered $[6,11,12]$. Thus the importance of making known its existence, anatomical and histopathological characteristics in lectures on histology and oral pathology: the professional and in particular the oral pathology specialist must consider its presence to avoid overdiagnosis and the implications this carries from the point of view of the treatment and prognosis of a patient diagnosed with cancer.

The way to make the differential diagnosis and rule out misinterpretation as a phenomenon of perineural tumour invasion $[1,6,25]$ lies in the cells of the JOO appearing to have a normal cytology, with no cellular or nuclear pleomorphism, with no atypical 
mitotic figures, no foci of inflammation or necrosis in the stroma [24], and with preservation of the epithelial basal membrane [20]. There is only one report of a benign tumour derived from cells of the $\mathrm{JOO}$ in the temporal region [21], and there is no evidence of a malignant lesion originating there.

\section{CONCLUSIONS}

We conclude that the $\mathrm{JOO}$ is a benign structure that can frequently be found in the normal anatomy of an individual. Its function has not been clarified, which is why it is presumed to be a dispensable structure, although knowledge of it is important to avoid the erroneous diagnosis of an invasive process from a malignant oral mucosa lesion.

\section{REFERENCES}

1. Brannon RB, Fowler CB. Intraneural epithelial islands associated with a periapical granuloma: a cause for concern? J Oral Maxillofac Surg. 2003; 61(6): 725-728, doi: 10.1053/ joms.2003.50144, indexed in Pubmed: 12796887.

2. Bommanavar SB, Hema KN, Baad R. Juxtaoral organ of Chievitz: An innocuous organ to be known. J Oral Maxillofac Pathol. 2017; 21(1): 162-164, doi: 10.4103/jomfp. JOMFP_22_17, indexed in Pubmed: 28479708.

3. Cheng E, Cohen MA, Scognamiglio T. Neuroepithelial structure resembling the juxtaoral organ of chievitz: usual morphology in an unusual location. Int J Surg Pathol. 2016; 24(8): 721-722, doi: 10.1177/1066896916660620, indexed in Pubmed: 27450986.

4. Chievitz JH. Chievitz juxtaparotid organ, free from cancer. Arch Anat Physiol. 1885; 9: 401-436, indexed in Pubmed: 26898269.

5. D'Andrea V, Malinovsky L, Biancari F, et al. The Chievitz juxtaparotid organ. G Chir. 1999; 20(5): 213-217, indexed in Pubmed: 10380360.

6. Danforth RA, Baughman RA. Chievitz's organ: a potential pitfall in oral cancer diagnosis. Oral Surg Oral Med Oral Pathol. 1979; 48(3): 231-236, indexed in Pubmed: 289927.

7. Dibal N, Garba S, Jacks T. Plastinates: possible tool for medical education in the near future: mini review. Res Dev Med Educ. 2018; 7(1): 3-7, doi: 10.15171/rdme.2018.002.

8. Grüneberg H. Exocrine glands and the Chievitz organ of some mouse mutants. J Embryol Exp Morphol. 1971; 25(2): 247-261, indexed in Pubmed: 5088022.

9. Ide F, Mishima K, Saito I. Juxtaoral organ of Chievitz presenting clinically as a tumour. J Clin Pathol. 2003; 56(10): 789-790, doi: 10.1136/jcp.56.10.789, indexed in Pubmed: 14514788.

10. Ito $M$, Nakashima $M$, Yoshioka $M$, et al. Organogenesis of the juxta-oral organ in mice. J Anat. 2009; 215(4): 452-461, doi: 10.1111/j.1469-7580.2009.01118.x, indexed in Pubmed: 19563471.

11. Kusafuka K, Kameya T. Juxtaoral organ of Chievitz, radiologically suspicious for invasion of lingual squamous cell carcinoma. Pathol Int. 2007; 57(11): 754-756, doi: 10.1111/j.14401827.2007.02161.x, indexed in Pubmed: 17922689.
12. Lutman GB. Epithelial nests in intraoral sensory nerve endings simulating perineural invasion in patients with oral carcinoma. Am J Clin Pathol. 1974; 61(2): 275-284, doi: 10.1093/ajcp/61.2.275, indexed in Pubmed: 4811744.

13. Mandl L, Nerlich A, Pankratz H, et al. [The juxta-oral organ (Chievitz organ) - a sensory organ in the bucco-temporal area?]. Pathologe. 1993; 14(4): 205-209, indexed in Pubmed: 7690134.

14. Mérida-Velasco JR, Rodríguez-Vázquez JF, de la Cuadra-Blanco C, et al. Morphogenesis of the juxtaoral organ in humans. J Anat. 2005; 206(2): 155-163, doi: 10.1111/j.14697580.2005.00377.x, indexed in Pubmed: 15730480.

15. Mikó T, Molnár P. The juxtaoral organ: a pitfall for pathologists. J Pathol. 1981; 133(1): 17-23, doi: 10.1002/ path.1711330103, indexed in Pubmed: 7205439.

16. Mills SE, Gaffey MJ, Frierson HF, et al. Tumors of the upper aerodigestive tract and ear. Washington DC: Armed Forces Institute of Pathology. 2000: 372-373.

17. Müller E, Zenker W. Enzyme-histochemistry of the juxtaoral organ in man ("organ of Chievitz"). Histochemistry. 1981; 71(2): 279-290, indexed in Pubmed: 6787002.

18. Ottone NE, Baptista CAC, Latorre R, et al. E12 sheet plastination: Techniques and applications. Clin Anat. 2018; 31(5): 742-756, doi: 10.1002/ca.23008, indexed in Pubmed: 29082560.

19. Palazzolo MJ, Fowler CB, Magliocca KR, et al. Neuroepithelial structures associated with the subepithelial nerve plexus of taste buds: a fortuitous finding resembling the juxtaoral organ of Chievitz. Oral Surg Oral Med Oral Pathol Oral Radiol. 2014; 117(4): 497-501, doi: 10.1016/j. oooo.2013.12.403, indexed in Pubmed: 24630162.

20. Pantanowitz L, Balogh K. Significance of the juxtaoral organ (of Chievitz). Head Neck. 2003; 25(5): 400-405, doi: 10.1002/hed.10209, indexed in Pubmed: 12692878.

21. Ramachar SM, Huliyappa HA. Accessory parotid gland tumors. Ann Maxillofac Surg. 2012; 2(1): 90-93, doi: 10.4103/22310746.95334, indexed in Pubmed: 23483721.

22. Ramsay A. Persistence of the organ of chievitz in the human. Anat Rec. 1935; 63(3): 281-293, doi: 10.1002/ ar.1090630308.

23. Roşu Ş, Neamțu C, Totolici B. Unusual lesion of the temporal region, benign tumor of the Chievitz's organ: a case report. Rom J Morphol Embryol. 2014; 55(2 Suppl): 683-685, indexed in Pubmed: 25178344.

24. Sancheti SM, Sawaimoon S, Zameer MA. Juxtaoral Organ of Chievitz, an Obscure Anatomical Structure Masquerading as Perineural Invasion of Mucoepidermoid Carcinoma: Case Report and Review of Literature. Int J Surg Pathol. 2015; 23(6): 461-463, doi: 10.1177/1066896915568991, indexed in Pubmed: 25627069.

25. Sil Ki, Hak Ki, Ho Ch, et al. Juxtaoral organ of Chievitz: a case report. Korean J Pathol. 2005; 39: 265-268.

26. Tschen JA, Fechner RE. The juxtaoral organ of Chievitz. Am J Surg Pathol. 1979; 3(2): 147-150, indexed in Pubmed: 532846 .

27. Zenker W. Organon bucco-temporale (Chievitzsches Organ), ein nervös epitheliales Organ beim Menschen. Anat Anz. 1953; 100: 257-265.

28. Zenker W. Die nervö sen Elemente des Chievitzschen Organs. Verh Anat Ges. 1959; 56: 249-258. 